\title{
TANULATLAN FELNŐTTEK VAGY KÉPZETLEN KORMÁNYZATI VEZETŐK?*
}

\author{
Tóth Judit ${ }^{1}$
}

Az UNESCO Felnőttoktatási Világkonferenciája már 1960-ban, Montrealban deklarálta az egész életen át tartó tanulás eszméjét és elkerülhetetlenségét. Az eredeti montreali eszme egyetemes emberi értékeket hordoz, olyan fejlesztést tételez fel, amely az általános müveltség és a szakmüveltségek harmonikus egységére épit, hogy minden személyiség minél teljesebben kibontakozhasson. A vizió arra is kiterjed, hogy a nevelés, a képzés egyszer megszünteti önmagát, mert átadja a helyét az önképzésnek. Ettöl még messze vagyunk, ahogyan az állam elhalásától is.

Az egész életre kiterjedő tanulás új modellje (lifelong learning) kiterjesztve és kiegészítve tartalmazza az élet egészére, vagyis a mindenből és mind módon tanulás (lifewide learning) elérését. Maga az élet is felfogható ugyanis egy tanulási, alkalmazkodási folyamatnak. Mindezen belül a felnőttképzés iskolarendszerbeli és azon kívüli formái egyszerre fejlesztendők, hogy a tanköteles korban meg nem szerzett tudást és képességeket kialakítsa (második és többedik esély), de magában foglalja a továbbképzést, a megváltozott élethelyzetekből adódó átképzési követelmények kielégítését, a hátrányos helyzetű társadalmi csoportok integrálódásának elősegítését ${ }^{2}$ és a müvelődés, a szabadidő hasznos eltöltésének a lehetőségét. Ezt a célt a felnőttképzési és közmüvelődési intézményrendszer szolgálja, amelyet mintegy ötezer képzési cég, valamint az informális oktatás és a távoktatás formái egészítenek ki. A tanulás biológiai, szociális, kulturális, anyagi képességeinek súlyos hiányával magyarázható talán, hogy Magyarországon a felnőtteknek, optimista becslések szerint csak a 8-9\%-a tanul, eltérően az EU által elvárt 12,5\%-nak, miközben a magyar cégek 18-37\%-a nyújt képzést dolgozóinak az EU 25-57\%-os átlagával szemben. A 15 évesnél idősebb népesség egynegyede pedig nem rendelkezik alapfokú végzettséggel. Vagyis a funkcionális analfabéták számának, arányának csökkentésében fontos szerepet kell vállalnia a felnőttképzésnek. Ezeknek az adatoknak a javulásához persze kell, hogy a felnőtt oktatókat kiképezzék, az elérhető európai tapasztalatokat átvegyék, a felnőttképzésbe bekapcsolódás pedig ne külső kényszer legyen, hanem saját, belső igény. Ha az élethosszig tartó tanulás örömet ad, az egyén életlehetőségeit kiteljesítő szerepe tudatosul,

\footnotetext{
${ }^{*}$ DOI 10.21867/KjK/2017.1.2.

${ }^{1} \mathrm{Dr}$. Tóth Judit CSc, tanszékvezető egyetemi docens, SZTE-ÁJK

2 Erről bővebben lásd a Szegedi Egyetem EduMAP projektjét: https://www.uszeged.hu/edumap/celkituzes/felnottkepzes-mint-aktiv (letöltés dátuma: 2017. október 2.)
} 
például úgy, hogy értékeli, minden új élethelyzet egyben tanulás is ${ }^{3}$. Ehelyett ma a felnőttképzésben az általános képzést (szakmai képzés, magasabb iskolai végzettség megszerzése) és az idegen nyelvi oktatást tartja kiemelten fontosnak a szakmai közönség.

A 2013. évi LXXVII. törvény a felnőttképzés bürokratizálódásáról szól, stratégiai irányokról aligha. A másfélszáz szakasz zöme a képzést nyújtók engedélyeztetéséről, valamint a sérült felnőtteknek adott képzések állami támogatásra pályázásáról, a minőségbiztosítás formai kérdéseiről és az adatszolgáltatásról rendelkezik. Például a felnőttképzést folytató intézmény képzési tevékenysége minőségének folyamatos javítása céljából a miniszter rendeletében meghatározott minőségbiztosítási keretrendszernek megfelelő minőségbiztosítási rendszert működtet, és a minőséget az állami hatóság legalább kétévente ellenőrzi. A hallgatói jogok alapja pedig az, hogy mindenkire egyaránt alkalmazható, aki nem tanköteles (16 év feletti) vagy tankötelesként felnőttképzésben is részt vesz. A szerencsések tehát 16 év felett még közoktatási intézményekben tanulnak, a kevésbé kiváltságosok pedig már felnőttképzési intézményben. A felnőttképzés persze nagyrészt saját vagy a munkáltatók zsebére megy, az állam - a szabályozáson, engedélyezésen, ellenőrzésen és adatgyüjtésen kívül - szerény támogatást nyújt a központi költségvetésből, valamint a szakképzési hozzájárulásról és a képzés fejlesztésének támogatásáról szóló törvény alapján, azzal, hogy a szakképzési hozzájárulásnak a szakképzési hozzájárulásra kötelezett által a saját dolgozói képzésére elszámolható egy része. Ezek terhére támogatás nyújtható annak a magyar és a nem magyar állampolgárnak, aki a szabad mozgás jogát Magyarországon gyakorolja, bevándorolt, letelepedett, befogadott, hontalan, menekült vagy oltalmazott). Végül a fogyatékos felnőttek képzéséhez a költségvetési törvényben meghatározott mértékü normatív támogatást nyújthat a kormányrendeletben meghatározott feltételekkel ${ }^{4}$ (pl. más támogatás hiányában) és a támogatási igények kielégítésére meghatározott sorrend szerint. Nem kell tagadni, hogy az elmúlt években a Nemzeti Foglalkoztatási Alap mellett jelentősebbek voltak az európai uniós forrásokból a felnőttek képzéséhez nyújtható, foglalkoztatás elősegítését célzó képzési támogatások. További megszorítás, hogy a támogatásban kizárólag a felelős miniszterrel a felnőttképzés támogatásáról szóló megállapodást kötő felnőttképzési intézmény részesülhet.

Ha jól olvasom, a 2017. évi költségvetésben a Szakképzési Centrumok által ellátott felnőtt oktatási tevékenységre 6 milliárd forintot szánnak, bár a szakképzési és felnőttképzési támogatás teljes összege 19 milliárd forint, és jut egy szük milliárd a centrumokban az ellátottak pénzbeli juttatásaira. Ez biztosan nem fedezi sem az igényeket, sem az egész életen át tartó tanulás

\footnotetext{
${ }^{3}$ Kaposi József előadása (2013): www.kaposijozsef.hu/wp-content/.../6.-Élethosszig-tartótanulás-felnőttek-képzése.ppt (letöltés dátuma: 2017. október 2.)

${ }^{4}$ 123/2007. (V. 31.) Korm. rendelet a felnőttképzési normatív támogatás részletes szabályairól
} 
keretstratégiáját, ${ }^{5}$ amely 2014-2020 között megszabja a szakpolitikai irányt, 120 oldalon. ${ }^{6}$ Igaz, abban egyértelmüvé teszik, hogy ,a keretstratégia megvalósítása elsődlegesen a Gazdasági Innovációs Operatív Program és az Emberi Erőforrás Operatív Program intézkedésein keresztül történik". Mégpedig úgy, hogy a megfelelö és kimutatható hatás érdekében az Európai Bizottság javaslata szerint a támogatások koncentrációjára van szükség. A stratégia nem vacakol sokat az egyéni önmegvalósítással, örömöt adó tanulással, az emberi személyiség kiteljesítésével, csakis foglalkoztatási és gazdaságfejlesztési kérdésekre figyel, ugyanis a „magyar gazdaság fejlesztéséhez nélkülözhetetlen a humán erőforrás fejlesztése, az aktív korú népesség foglalkoztathatóságának és versenyképességének folyamatos javítása", ide értve a cégek, kisvállalkozások versenyképességét is. Megemlíti, hogy van szociális következménye is az efféle fejlesztésnek, azaz egészében ,a tágan értelmezett humán tőke fejlesztéséről” van szó. A stratégia hangsúlyozza, hogy ,a munkaalapú társadalom és a teljes foglalkoztatottság elérése érdekében a foglalkoztatás bővítéséhez és a munkavállalók alkalmazkodóképességének és versenyképességének javításához szükséges a valós reálgazdaság igényeinek és a növekedési potenciállal rendelkező ágazatok képesítési szükségleteinek megfelelő és ahhoz rugalmasan igazodó, versenyképes tudást biztosító képzési és egész életen át tartó tanulási rendszer megteremtése". További cél, hogy a foglalkoztatás bővítése érdekében - és nem az önálló élet, a társadalmi hasznosság érdekében- alapvetőnek tekintik ,a hátrányos helyzetü álláskeresők és inaktívak, kiemelten az alacsony iskolai végzettségüek, tartós munkanélküliek, romák, az idősek, a fiatalok, a kisgyermeket nevelők munkaerőpiaci részvételének és foglalkoztathatóságának javítását, az elsődleges munkaerőpiacra történő belépésük támogatását”. Végül eljut odáig a stratégiai gondolkodás, hogy ,,a tanulási, kulturális, közművelődési infrastrukturális fejlesztéseken és a közszolgáltatásokhoz való hozzáférés javításán keresztül az életminőség javítása" felé haladjunk, a szükséges társadalmi partnerekkel, az érintett területek szakmai és civil szervezeteivel való konzultációja alapján.

A megvalósítás nyomon követésének kidolgozását csak a stratégia elfogadása utánra tervezték az EMMI indikátor munkacsoportja vezetésével. „A monitoring adatok előállításában, összegyüjtésében, rendszerezésében nagyban támaszkodunk a háttérintézmények szakértői bázisára. A monitoring-jelentést kétévente - a kormányzat stratégiaalkotási elöírásaival összhangban összeállítjuk és a kormány honlapján nyilvánosságra hozzuk.” Kérem, szóljon, aki ezt olvasta!

http://www.kormany.hu/download/7/fe/20000/Eg\%C3\%A9sz\%20\%C3\%A9leten\%20\%C3\%A1t \%20tart\%C3\%B3\%20tanul\%C3\%A1s.pdf (letöltés dátuma: 2017. október 2.) 
Pedig nem előzmény nélküli a felnőttképzési, egész életen át tartó tanulás stratégiája, hiszen 2005 szeptemberében, igaz, csak 60 oldalas anyagban határozták meg ${ }^{7}$ ennek céljait, eszközeit és forrásait a stratégiájában. Abban kiemelték, hogy a hazai és az uniós források bővülése mellett a modellben a keresleti oldal fejlesztésére nagyobb figyelmet kell fordítani, hiszen a fejlett országokban a tanulásba való befektetésnek olyan modellje vált uralkodóvá, „amely az egész életen át tartó tanulás finanszírozását a társfinanszírozás elvére alapozza. A társfinanszírozási modellek - az egész életen át tartó tanulás tanulóközpontú és kereslet-irányította orientációjával összhangban - többnyire olyan új pénzügyi ösztönzők és eszközök alkalmazására épülnek, amelyek célja az egyének támogatása, különösen azok esetében, akiknél a részvétel akadályát a tanulás költségei jelentik." Ugyanis a felnőttképzési törvény végrehajtási rendeletei akkor megteremtették a pénzügyi érdekeltséget a szolgáltatók oldalán, azonban továbbra sem volt egyértelmü, hogy hogyan motiválhatók és ösztönözhetők a felnőttek tömegei az egész életen át tartó tanulásban való részvételre. „Különösen problematikus ez a munkaerő-piaci képzésekkel eddig el nem ért, alacsony végzettségü, hátrányos helyzetü népesség esetében. A kereslet ösztönzését segíteni tudja a meglévő költségvetési források hatékonyabb felhasználása."

Ezt fejtette ki az Állami Számvevőszék háttérelemzése 2009-ben. ${ }^{8}$ A holland, német, lengyel és magyar felnőttképzési rendszer összevetése alapján egyértelmü, hogy Magyarország a felnőttképzési stratégiai célértékeket illetően elmaradásban van az EU tagállamaihoz képest: az egész életen át tartó tanulásban a magyar 25-64 év közötti népesség mindössze 3,1 százaléka vesz részt felnőttképzésben, szemben az EU25-ök 9,6 százalékos átlagával (és ezek az adatok azóta sem javultak.) A felnőttképzés mai struktúrája és a képzésbe vontak száma nem követi a halmozottan hátrányos helyzetüek aktív népességben és munkanélküli regisztrációban megfigyelhető struktúráját. Magyarországon a felnőtt korú népesség közel 16\%-a funkcionális analfabéta, nem képes az írás és olvasás képességét a mindennapi élete során ténylegesen használni. Emellett a népesség több mint 30\%-a alulképzett, ami hátráltatja, hogy válsághelyzetben munkahelyet, szakmát, lakóhelyet tudjon váltani. A hazai felnőttképzés problémája továbbá, hogy az alacsony képzettségü célcsoportok a lakóhelyükön nem juthatnak közvetlenül felzárkóztató képzésekhez, mert ott nem kifizetődő a piaci szolgáltatás-kínálat. A felnőttképzésen belül a szakképzés és a szakmai továbbképzés a meghatározó. A jogszabály említi ugyan az ,általános célú felnöttképzést" is, de a gyakorlatban kevés olyan lehetőséget nyújt, amely biztosíthatná az ilyen jellegü

\footnotetext{
$7 \mathrm{Az}$ egész életen át tartó tanulás stratégiájának megvalósítását szolgáló feladatokról szóló 2212/2005. (X. 13.) Korm. határozat, összefüggésben a felnőttképzés fejlesztésének irányelveiröl és cselekvési programjáról szóló 1069/2004. (VII. 9.) Korm. határozatban foglaltakra.

${ }^{8}$ Forrás:

https://www.asz.hu/storage/files/files/Szakmai\%20kutat\%C3\%A1s/2009/t312.pdf?ctid=739 (letöltés dátuma: 2017. október 2.)
} 
képzések jelentős növekedését, jóllehet ezek a képzési formák lennének képesek pótolni az alapképzettségbeli hiányokat, ami pedig előfeltétele lenne a társadalmi hátrányok mérséklésének, ezzel együtt a felnőttképzés hatékonysága javításának. A felnőttképzés és az egész életen át tartó tanulás fő gazdasági célja (a munkaerő-piaci igények minél teljesebb kielégítése) mellett nagyon fontosak a társadalompolitikai céljai is: az esélyegyenlőség és a társadalmi befogadás előmozdítása. A felnőttképzés az az eszköz, amellyel a kirekesztődési spirál megtörhető. Ugyanakkor a magyar adatok és a nemzetközi összehasonlítások azt mutatják, hogy e téren a magyar felnőttképzési rendszer nagyon gyengén teljesít. Magyarország az iskolarendszeren kívüli felnőttképzés esetében a piaci modell mellett döntött. Ez a modell élénk versenyt és gazdag, sokszínü képzési kínálatot eredményez. A magyar szabályozás látszólag korszerü a tekintetben, hogy a felnőttképzési kínálattal szemben nagyon komoly minőségi és fogyasztóvédelmi követelményeket állít. Érdemes megvizsgálni, hogy ezek a gyakorlatban hogyan érvényesülnek. Ugyanakkor a piaci modell két nagy veszélye az, hogy a piac kínálat-vezéreltté válik, és ezáltal a leginkább rászorulók nem jutnak hozzá megfelelő mértékben a nekik szükséges képzéshez. Ezért az ellenőrzésnek kiemelt figyelmet kellene szentelni azokra az intézkedésekre, amelyek révén e piac kereslet-vezéreltsége erösíthető, és megakadályozható, hogy a leghátrányosabb helyzetben lévők alulreprezentáltak legyenek a felnőttképzésben vagy teljesen kiszoruljanak a képzési rendszerből.

A felnőttképzés finanszírozási rendszere négycsatornásból kétcsatornássá vált ugyan, de jelentösen növekedtek az ilyen célra felhasználható európai források. A felhasználás első tapasztalatai ellentmondásosak, az átlagos képzési költségek jelentősen emelkednek, bár javul a leghátrányosabb helyzetü rétegek részvételi aránya a felnőttképzésben. Az elhelyezkedés eredményessége nehezen mérhető. Ennek alapján indokolt a vizsgálatban kiemelten foglalkozni az EU pénzek felnőttképzési felhasználásával, ráadásul úgy, hogy igazából azt kellene megvizsgálni, hogy a felnőttképzési célok hogyan épültek be az egyes szakpolitikákba (szerkezetileg, tartalmilag, módszertanilag a társadalompolitikába, az információs és kommunikációs politikába, a finanszírozási politikába), ahogy azt paradigmatikusan összefoglalta Halász Gábor. Azt meg én teszem hozzá, hogy az 1990-es években a GDP egy százalékát kitevő felnőttképzési közkiadást ma közmunkára költik, amelyben nincs semmiféle képzési tartalom, azaz ideje emiatt is sürgetni a szemléletváltást!

A felnöttképzésben jártasak sürgetik a paradigma-váltást, hogy a döntéshozók is felismerjék: a felnöttképzés a 21. században kulcs iparág. A legföbb problémákat illetöen csatlakozni tudok Pásztor Eszter blogján leirtakhoz, ${ }^{9}$

9 http://pasztoreszter.blogspot.hu/2017/05/mi-tanfolyamaid-igazi-erteke.html (letöltés dátuma: 2017. október 2.) 
miszerint a felnöttek részvétele a képzésekben az európai átlaghoz képest rendkivül alacsony. A felnöttképzés túlszabályozott, ami nem ösztönzi a képzések indítását. Mindemellett pedig túlságosan magasak az óraszámok, ami nehezen fér bele a felnöttek idejébe.

\section{Források jegyzéke:}

- https://www.asz.hu/storage/files/files/Szakmai\%20kutat\%C3\%A1s/200 9/t312.pdf?ctid=739

- http://pasztoreszter.blogspot.hu/2017/05/mi-tanfolyamaid-igazierteke.html

- www.kaposijozsef.hu/wp-content/.../6.-Élethosszig-tartó-tanulásfelnőttek-képzése.ppt

- http://www.kormany.hu/download/7/fe/20000/Eg\%C3\%A9sz\%20\%C3 \%A9leten\%20\%C3\%A1t\%20tart\%C3\%B3\%20tanul\%C3\%A1s.pdf

- https://www.u-szeged.hu/edumap/celkituzes/felnottkepzes-mint-aktiv

- Az egész életen át tartó tanulás stratégiájának megvalósítását szolgáló feladatokról szóló 2212/2005. (X. 13.) Korm. határozat,

- a felnőttképzés fejlesztésének irányelveiről és cselekvési programjáról szóló 1069/2004. (VII. 9.) Korm. határozat 